\title{
Timing of Crop Removal Has Limited Effect on Merlot Grape and Wine Composition
}

\author{
Petra D. King1, Richard E. Smart², Daniel J. McClellan'1 \\ ${ }^{1}$ School of Viticulture and Wine Science, Eastern Institute of Technology, Hawke's Bay, New Zealand \\ ${ }^{2}$ Smart Viticulture, 31 North Corner, Newlyn near Penzance TR185JG, Cornwall, UK \\ Email: pking@eit.ac.nz
}

Received 30 March 2015; accepted 25 April 2015; published 28 April 2015

Copyright (C) 2015 by authors and Scientific Research Publishing Inc.

This work is licensed under the Creative Commons Attribution International License (CC BY).

http://creativecommons.org/licenses/by/4.0/

(c) (i) Open Access

\begin{abstract}
Cluster removal during the growing season is a widely utilized vineyard management practice aiming to balance crop load to the capacity of the vine to ripen the fruit. Research was undertaken over two growing seasons (2008-2009) in Hawke's Bay, a cool climate region of New Zealand, to establish the influence of different times of crop removal on Merlot vine growth and fruit and wine composition. The test vineyard was high-yielding, to $23 \mathrm{t} / \mathrm{ha}$, and vigorous. A commercial standard of apical cluster thinning to remove 20 clusters per vine from vines with ca 44 clusters in 2008 and ca 47 in 2009, was carried out on uniform vigour, 7yo grafted Merlot vines at nine times between prebloom and six weeks post veraison. The 2009 season was naturally higher yielding. Timing of crop removal had no significant effect on vine vegetative growth in terms of enhanced shoot growth as measured by cane weights at pruning, or canopy leaf density. Time of thinning also had no effect on overall grape yield, cluster weight, and berry weight. There were limited effects on fruit ripeness in one season (2009) at the veraison time of thinning only, with increased Brix and lower TA levels. Berry anthocyanin concentrations were enhanced by cluster thinning in 2008, and more so when undertaken at or soon after veraison. There was however no influence of removal timing on anthocyanin levels and total phenolics in the wines. Grape ripeness, must and wine composition tended to respond more from crop removal at veraison than the other times evaluated. Data suggest that vine response was modified by excessive leafiness and shading.
\end{abstract}

\section{Keywords}

Crop Removal, Timing, Merlot, Grape Composition, Wine

\section{Introduction}

Problems with attaining optimum ripening and minimising variability in maturity within vineyards are due to a

How to cite this paper: King, P.D., Smart, R.E. and McClellan, D.J. (2015) Timing of Crop Removal Has Limited Effect on Merlot Grape and Wine Composition. Agricultural Sciences, 6, 456-465. http://dx.doi.org/10.4236/as.2015.64045 
range of soil, climatic and cultural factors. An imbalance between vegetative and fruiting phases of vine growth is a major contributor to this variation in ripening and grape composition. Management practices commonly used to compensate for this imbalance involve manipulation of canopy architecture through trellising and training systems, and crop removal to balance the ability of the vine leaf area to ripen fruit. The variety Merlot is different from most other wine grape varieties, with large clusters and large berries, hence a high yield potential. In New Zealand's Hawke's Bay vineyards, crop removal from Merlot vines is undertaken each season as standard management between fruit set and harvest, for perceived benefits of improving grape composition and wine quality. We evaluate the impact of timing of this operation here.

There is a considerable body of literature reporting crop removal responses on grape and wine composition for a wide range of cultivars and growing conditions. A recent example shows advanced maturity, decreased acidity and increased anthocyanins and phenolics in Cabernet Sauvignon in the hot Riverland and Sunraysia regions of Australia with crop thinning [1]. A study with Shiraz in the warm Barossa Valley of Australia found decreasing yield per vine significantly increased wine colour and phenolics, and improved levels of metabolites which contribute to wine aroma and flavour [2]. Reducing Cabernet Sauvignon yield in Napa Valley, Californiaby varying winter bud numbers or cluster showed yield influenced astringency and vegetative flavours, but had little effect on wine aroma [3]. Cluster thinning was noted to increase Brix and enhanced wine colour, aroma and flavour [4] in Pinot noir in cooler Oregon and British Colombia vineyards, and reduced TA, increased $\mathrm{pH}$, Brix, terpenes and increased wine colour, and herbaceous/grassy aroma in Chardonnay Musque cv in Ontario [5].

Some of this research has involved cluster removal post-bloom (around the modified Eichhorn-Lorenz (E-L) 29 - 31 growth stage as described in [6]-[10], or at veraison [3] [11]-[13]. Other workers claimed that the best time to cluster thin to affect maturity is prior to veraison [14]. In addition, it was noted that crop levels can be predicted with more certainty later in the season, and that less ripe, later set clusters are more visually evident at veraison [15].

Research has also examined the influence of the time of thinning relative to the benefits. Early pre-bloom to bunch set thinning enhances berry fresh and dry weights in table grapes [16], and is commonly used to enhance berry size. Several studies have investigated the influence on vine growth, grape ripening and grape and wine composition of cluster thinning at a range of times from pre-bloom to veraison [5] [15] [17] [18].

In addition to these mostly positive effects from crop load reduction, there are several studies in which cluster thinning has no effect. Cluster removal in Cabernet Sauvignon vines in the Napa Valley has produced little benefit to either grape ripeness or must composition and wine color [3] [7] [12], and in British Colombia [18].

The reported and apparently conflicting results make identification of any optimum time for crop reduction difficult to determine. Some positive effects on grape and wine composition from crop removal at veraison were reported with Merlot in NZ [19]. To investigate the optimum time for removal under Hawke's Bay conditions, the present study was undertaken over two seasons. The objectives were to evaluate a range of crop removal times between prebloom and post-veraison on Merlot grape and wine composition in a high yielding, and vigorous commercial vineyard.

\section{Materials and Methods}

\subsection{Study Area and Time}

The studies were undertaken over the 2007-2008 and 2008-2009 growing seasons in the premium red wine production area of Hawke's Bay in the North Island of New Zealand. Subsequently growing seasons will be identified by the year of harvest i.e. 2008 or 2009. Study plots were selected on a commercial vineyard within the Bridge Pa Triangle growing area, in a block of Merlot vines, clone 181 on 3309 rootstock, planted in 1999 at 1.6 $\mathrm{m}$ vine $\times 2.4 \mathrm{~m}$ row (2604 vines/ha) spacings on a Takapau sandy loam on a gravels soil type [20]. Growth and overall canopy vigour of the vines was even within the block. Vine trunk circumference was measured $30 \mathrm{~cm}$ above soil level in winter 2007, and measurement vines selected on the basis of uniformity of trunk circumference $(12.6 \mathrm{~cm} \pm 1.2 \mathrm{~cm})$ within a plot. There were nine timing of thinning treatments and an unthinned control.

\subsection{Experimental Design}

Each treatment was replicated four times in a randomised block design. Within each plot, two vines of the five 
were permanently tagged and all measurements were confined to these vines. All vines were pruned to two canes with a target of around 25 buds which did not differ by more than $5 \%$, and is the commercial standard. Vines were trained to a vertical shoot positioned (VSP) system. At this site and for this variety, bud break occurs around the beginning of October, 80\% capfall mid-December, veraison mid-February and harvest at 23 - 24 Brix at the start of April. Shoot thinning was undertaken at the head of the vine in late October in both seasons to reduce excessive shading. Commercial leaf removal was undertaken on all vines at 6 January 2008 and 29 December 2008 prior to pre-bunch closure, (stage E-L 32) in the two seasons. A Collard air pulsed vine trimmer machine was used to remove some of the leaves in the fruit zone so that fruit clusters were more visible. All other canopy manipulations and viticulture inputs were undertaken in accordance with the commercial specifications and performed uniformly across all treatments. Cluster thinning was undertaken at each of the treatment phenological stages with shoots being thinned to a single cluster per shoot by removal of apical clusters only. There was no attempt to achieve a fixed target of clusters per vine; rather the standard commercial method used on the vineyard was followed.

\subsection{Measurement and Data Analysis}

Canopy density was quantified using Point Quadrant Analysis (PQA) in mid-February 2008. PQA was undertaken in each plot across 2 measurement vines and at 5 different heights above the fruiting wire (200, 300, 400, 500 and $650 \mathrm{~mm}$ ). Methodology was the same as described [19].

Canopy surface area was calculated as per the methodology detailed in [21] based on $2.4 \mathrm{~m}$ vine spacing, a $1.3 \mathrm{~m}$ high canopy at trimming, and $0.4 \mathrm{~m}$ canopy width. Canopy surface areas were similar for each treatment due to the influence of regular canopy trimming, and were $3.0 \mathrm{~m}^{2} / \mathrm{m}$ row spacing, $4.8 \mathrm{~m}^{2}$ per vine, and 12,500 $\mathrm{m}^{2} /$ ha.

Temperatures were continuously measured at one point within the block just below the fruit zone using an "e" Temp Thermocron temperature logger (Rollex Group, Vic. Australia) recording data every 30mins. The loggers were shielded within a well-ventilated screen sited just below the cordon wire.

Harvest was undertaken on 4 April 2008 and 30 March 2009. Grapes were harvested separately for each measurement vine recording yield and cluster number per vine. One measurement vine within each plot was selected at random and the basal cluster was harvested from 3 shoots per vine, randomly selected and spaced along the cordon at the proximal and distal points, and halfway between. These were used for berry weight and anthocyanin measurement using spectrophotometric methods [22] [23].

All grapes were refrigerated at $2^{\circ} \mathrm{C}$ for a minimum of 8 hours before further processing for wine. Wines were made from each plot with the grapes from two vines being combined to make 3.5 - $4.5 \mathrm{~kg}$ ferments and with four replicates. Grapes were destemmed and crushed using an Enoveneta crusher destemmer (Enoveneta S.p.A., Padova, Italy). Samples of must were taken immediately after crushing and soluble solids ( ${ }^{\circ}$ Brix), must titratable acidity (TA), and $\mathrm{pH}$ were measured. Additions of $\mathrm{SO}_{2}$ at a rate of $30 \mathrm{mg} / \mathrm{kg}$ were made using post crush weight. Musts were chaptalized by the addition of sucrose to raise ${ }^{\circ}$ Brix to the maximum attained within the trial. Fermentations were in food grade $5 \mathrm{~L}$ plastic containers. Must was warmed to $15^{\circ} \mathrm{C}$ and inoculated with Lavlin EC1118 yeast (Carter and Associates, Auckland, NZ) at a rate of $250 \mathrm{mg} / \mathrm{kg}$ of must. Di-ammonium phosphate (DAP) was added at the rate of $300 \mathrm{mg} / \mathrm{L}$. Superfood (Pacific Rim Oenology, Blenheim, NZ) a yeast nutrient, was added at a rate of $250 \mathrm{mg} / \mathrm{L}$ of must.

Fermentations were undertaken in a room maintained at $26^{\circ} \mathrm{C}$. Wine was fermented in contact with skins for 18 days, with the cap plunged daily. Wine was pressed in a Pillan 20L, 4 Bar, hydraulic press (Enotecnica PILLAN, Vicenza, Italy). Marc was pressed to give $70 \%$ yield of post-crush weight in litres, and 60 mg/l SO 2 was added. Malolactic fermentation was inhibited by the addition of $\mathrm{SO}_{2}$ and refrigeration at $0^{\circ} \mathrm{C}$. Wines were allowed to settle for two days, racked then returned to $0^{\circ} \mathrm{C}$ storage for four weeks before a final racking. Wine was sparged with $\mathrm{NO}_{2}$ gas for 5 minutes before bottling, as were the bottles before filling by siphon.

At bottling, samples were taken from each wine and analysed using a High Performance Liquid Chromatograph (HPLC). TheHPLC was a Shimadzu LC-10AT solvent delivery system equipped with a DGU-14A online de-gassing unit, an SPD M20A photo diode array detector, a CTO-10ASvp column oven, an SIL-10ADvp auto injector set to inject $20 \mu \mathrm{L}$ of sample, with a 10ADvp sample cooler, connected to an SCL-10Avp system controller and controlled by Shimadzu's LC solutions software.

The column used for the phenolic separations was a Gemini $5 \mu$ C18 110A column, $250 \times 4.6$ mm from Phe- 
nomenex, fitted with a guard column of the same material. The gradient used for the separations consisted of $0.2 \%$ Tri fluoroacetic acid in water (A) and acetonitrile (B), with a flow rate of $1 \mathrm{~mL} /$ minute. Solvents were filtered and de-gassed using $0.45 \mu \mathrm{m}$ regenerated cellulose filters by Sartorius. Samples were filtered directly into glass sampling vials fitted with Teflon coated liners, using Poly Vinyl Di Fluoride (PVDF) filters from Bonnet equipment with a pore size of $0.45 \mu \mathrm{m}$. Data were collected from the samples at 280, 320, 360, and $520 \mathrm{~nm}$. All retention times for relevant peaks were identified from the relevant standards and calibration curves.

All data were analysed for statistical significance by two-way ANOVA using Minitab 15 statistical software (Minitab Inc., State College, PA).

\section{Results}

\subsection{Canopy Leaf Area}

Point Quadrat Analysis was carried out on 14 February 2008 in the first season of the study, measuring only thinning treatments carried out prior to and including veraison plus the control. Canopy leaf area was calculated from this data averaged over the five heights, using the method described in [24]. The results in Table 1 show similar canopy density as expressed as leaf layer number and canopy leaf area over the six treatments.

In the absence of crop removal there was a small (6\%) but significant decrease in leaf area of control vines, indicating some compensation of vine growth due to competition with fruit. Data of Table 1 also show the very high Leaf Layer Number (LLN) values relative to the optimum values proposed in [21] which indicate very dense leaf canopies and excessive shade.

\subsection{Harvest Data}

The yield data for each of the treatments for the 2008 and 2009 harvests are shown in Table 2. The average yield of the unthinned control was high in both years, at 15.9 and $22.7 \mathrm{t} / \mathrm{ha}$ respectively. These values are higher than, and around double the normal yield of other wine grape varieties in this region. Yields in 2009, a season of higher cluster number and fruit set, were $43 \%$ higher than 2008. In both seasons, cluster removal resulted in significantly reduced yield. There was a trend for yields to be lower for those vines thinned at veraison and later. Mean cluster weights were about 35 g higher in 2009 compared with 2008, which reflected the berry weight being about $20 \%$ higher in 2009. Berry weights were not recorded for the three post-veraison treatments due to experimental error. There appeared to be no systematic effect of timing of thinning on neither cluster weight nor berry weight, with treatment differences being relatively small.

\subsection{Seasonal Temperatures}

The seasonal temperatures for the 2007/08 and 2008/09 seasons are shown in Table 3, as the highest maximum and lowest minimum temperature occurring each month, and Growing Degree Days (GDD) calculated as the

Table 1. Effect of timing of cluster removal on Merlot vine canopies, point quadrat analysis, 14 February 2008.

\begin{tabular}{ccc}
\hline Time of cluster removal & Leaf Layer No/Vine & Canopy leaf area $\mathrm{m}^{2} / \mathrm{vine}$ \\
\hline Inflorescence swelling & 2.8 & 11.4 \\
$80 \%$ capfall & 2.7 & 11.0 \\
Fruit set & 2.7 & 11.1 \\
Bunch closure & 2.8 & 11.4 \\
Veraison & 2.8 & 11.3 \\
Control & 2.6 & 10.6 \\
Optimum levels & $1.0-1.5$ & - \\
\hline
\end{tabular}

There was no significant differences between treatments $(\mathrm{P}=0.05)$; Optimum levels ${ }^{1}$ see Smart and Robinson (1991). 
Table 2. Effect of time of cluster removal on Merlot yield data at harvest 2008 and 2009.

\begin{tabular}{ccccccccc}
\hline \multirow{2}{*}{ Thinning Treatment } & \multicolumn{2}{c}{ No clusters/vine } & \multicolumn{2}{c}{ Yield kg/vine } & \multicolumn{2}{c}{ Mean Berry wt g } & \multicolumn{2}{c}{ Mean Cluster wt g } \\
\cline { 2 - 9 } & 2008 & 2009 & 2008 & 2009 & 2008 & 2009 & 2008 & 2009 \\
\hline Control & $43.5 \mathrm{~b}^{\mathrm{a}}$ & $47.3 \mathrm{~b}$ & $6.1 \mathrm{~b}$ & $8.70 \mathrm{a}$ & $1.37 \mathrm{a}$ & $1.65 \mathrm{bc}$ & $126.1 \mathrm{a}$ & $181.6 \mathrm{a}$ \\
Inflorescence swelling & $23.3 \mathrm{a}$ & $30.6 \mathrm{a}$ & $4.46 \mathrm{ab}$ & $6.44 \mathrm{ab}$ & $1.44 \mathrm{a}$ & $1.63 \mathrm{bc}$ & $191.6 \mathrm{~b}$ & $211.2 \mathrm{bc}$ \\
80\% capfall & $25.3 \mathrm{a}$ & $29.3 \mathrm{a}$ & $4.33 \mathrm{ab}$ & $7.17 \mathrm{bc}$ & $1.37 \mathrm{a}$ & $1.67 \mathrm{bc}$ & $178.3 \mathrm{~b}$ & $245.8 \mathrm{~d}$ \\
Fruitset & $23.1 \mathrm{a}$ & $29.9 \mathrm{a}$ & $4.17 \mathrm{ab}$ & $6.68 \mathrm{ab}$ & $1.34 \mathrm{a}$ & $1.60 \mathrm{ab}$ & $187.1 \mathrm{~b}$ & $225.3 \mathrm{~cd}$ \\
Bunch closure & $23.6 \mathrm{a}$ & $29.1 \mathrm{a}$ & $4.38 \mathrm{ab}$ & $6.02 \mathrm{ab}$ & $1.44 \mathrm{a}$ & $1.82 \mathrm{c}$ & $182.3 \mathrm{~b}$ & $205.1 \mathrm{bc}$ \\
Veraison & $21.4 \mathrm{a}$ & $25.4 \mathrm{a}$ & $3.80 \mathrm{a}$ & $4.87 \mathrm{a}$ & $1.33 \mathrm{a}$ & $1.55 \mathrm{ab}$ & $172.2 \mathrm{~b}$ & $192.6 \mathrm{ab}$ \\
Veraison + 2 weeks & $22.6 \mathrm{~b}$ & $26.0 \mathrm{a}$ & $3.72 \mathrm{a}$ & $5.08 \mathrm{a}$ & $\mathrm{nm}$ & $1.68 \mathrm{bc}$ & $169.2 \mathrm{~b}$ & $194.4 \mathrm{ab}$ \\
Veraison + 4 weeks & $19.2 \mathrm{~b}$ & $24.1 \mathrm{a}$ & $3.31 \mathrm{a}$ & $4.86 \mathrm{a}$ & $\mathrm{nm}$ & $1.48 \mathrm{a}$ & $179.8 \mathrm{~b}$ & $200.8 \mathrm{ab}$ \\
Veraison + 6 weeks & $22.3 \mathrm{a}$ & $24.6 \mathrm{a}$ & $3.68 \mathrm{a}$ & $5.14 \mathrm{a}$ & $\mathrm{nm}$ & $1.55 \mathrm{ab}$ & $177.1 \mathrm{~b}$ & $210.6 \mathrm{bc}$ \\
\hline
\end{tabular}

${ }^{\mathrm{a}}$ Values with the same letter within the same column do not differ significantly ( $\left.\mathrm{P}>0.05\right)$; ${ }^{\mathrm{b}}$ not measured.

Table 3. Comparison of below vine canopy temperature data of Merlot vines for 2007/08 and 2008/09 season, period 1 October-harvest.

\begin{tabular}{|c|c|c|c|c|c|c|c|c|}
\hline 2007/08 & October & November & December & January & February & March & $\begin{array}{c}\text { Total Oct } \\
\text { Harvest }\end{array}$ & $\begin{array}{c}\text { Total Jan } \\
\text { Harvest }\end{array}$ \\
\hline Monthly max temp ${ }^{\circ} \mathrm{C}$ & 24.5 & 28.4 & 29.1 & 31.6 & 30.9 & 28.8 & \multirow{6}{*}{1318} & \multirow{6}{*}{817} \\
\hline Monthly Min Temp ${ }^{\circ} \mathrm{C}$ & 2.5 & 3.9 & 7.6 & 7.7 & 8.2 & 7.0 & & \\
\hline $\mathrm{GDD}^{\mathrm{b}}{ }^{\circ} \mathrm{C}$ & 109 & 160 & 252 & 290 & 269 & 238 & & \\
\hline Mean temp ${ }^{\circ} \mathrm{C}$ & 13.9 & 15.4 & 17.9 & 19.1 & 18.6 & 17.1 & & \\
\hline \multicolumn{7}{|l|}{ 2008/09 } & & \\
\hline Monthly max temp ${ }^{\circ} \mathrm{C}$ & 22.4 & 27.9 & 28.6 & 30.2 & 29.7 & 26.3 & & \\
\hline Monthly min temp ${ }^{\circ} \mathrm{C}$ & 5.2 & 5.9 & 10.9 & 9.9 & 11.9 & 8.3 & \multirow{3}{*}{1426} & \multirow{3}{*}{831} \\
\hline $\mathrm{GDD}^{\mathrm{b}}{ }^{\circ} \mathrm{C}$ days & 57 & 248 & 301 & 311 & 292 & 218 & & \\
\hline Mean temp & 13.4 & 16.2 & 19.1 & 19.6 & 19.5 & 16.4 & & \\
\hline
\end{tabular}

Harvest $=4 / 04 / 08$ and 30/03/09; GDD $^{\mathrm{b}}=$ Growing Degree Days (base $10^{\circ} \mathrm{C}$ ).

sum for each month of the average temperature (maximum plus minimum divided by two, and minus $10^{\circ} \mathrm{C}$ ). Comparison of the GDD from 1 October until harvest confirms the 2009 season as being slightly hotter than 2008 by $8 \%$.

\subsection{Must Analysis}

Must composition at harvest for both seasons are shown in Table 4. Associated with the lower crop loads of 2008, fruit was riper than in 2009 in terms of higher sugar (Brix) and lower titratable acidity (TA). In 2008 the time of cluster removal had no significant effect on ripeness in terms of Brix, TA and $\mathrm{pH}$. In contrast, both Brix and TA were significantly higher and lower respectively relative to the unthinned control for most times of thinning in 2009, the season of higher yield. Berry anthocyanin levels were significantly increased by all but two timing treatments in 2008, although only the veraison thinning time was significantly higher than the control in 2009. 
Table 4. Summary of must composition and berry anthocyanin levels in Merlot at havest 2008 and 2009.

\begin{tabular}{|c|c|c|c|c|c|c|c|c|}
\hline \multirow{2}{*}{ Treatment } & \multicolumn{2}{|c|}{ Brix } & \multicolumn{2}{|c|}{$\mathrm{TA} g / \mathrm{L}$} & \multicolumn{2}{|c|}{$\mathrm{pH}$} & \multicolumn{2}{|c|}{ Anthocyanins ${ }^{\mathrm{b}} \mathrm{mg} / \mathrm{g}$} \\
\hline & 2008 & 2009 & 2008 & 2009 & 2008 & 2009 & 2008 & 2009 \\
\hline Control & 23.4 & $22.2 \mathrm{ab}^{\mathrm{a}}$ & 5.10 & $5.61 \mathrm{c}$ & 3.47 & 3.23 & $1.4 \mathrm{a}$ & $1.29 \mathrm{a}$ \\
\hline Inflorescence swelling & 24.3 & $23.5 \mathrm{abc}$ & 4.30 & $4.73 \mathrm{ab}$ & 3.55 & 3.32 & $1.86 \mathrm{~b}$ & $1.52 \mathrm{ab}$ \\
\hline $80 \%$ capfall & 24.0 & $23.0 \mathrm{abc}$ & 4.27 & $4.84 \mathrm{ab}$ & 3.54 & 3.35 & $1.78 \mathrm{~b}$ & $1.40 \mathrm{ab}$ \\
\hline Fruitset & 24.0 & $23.1 \mathrm{abc}$ & 4.34 & $4.95 \mathrm{abc}$ & 3.51 & 3.29 & $1.73 \mathrm{~b}$ & $1.50 \mathrm{ab}$ \\
\hline Bunch closure & 23.6 & $23.3 \mathrm{abc}$ & 4.45 & $5.06 \mathrm{abc}$ & 3.53 & 3.39 & $1.66 \mathrm{ab}$ & $1.39 \mathrm{ab}$ \\
\hline Veraison & 24.2 & $24.0 \mathrm{c}$ & 4.28 & $4.46 \mathrm{a}$ & 3.57 & 3.35 & $1.92 \mathrm{~b}$ & $1.62 \mathrm{~b}$ \\
\hline Veraison +2 weeks & 24.0 & $23.6 \mathrm{bc}$ & 4.39 & $4.83 \mathrm{ab}$ & 3.49 & 3.34 & $1.77 \mathrm{~b}$ & $1.45 \mathrm{ab}$ \\
\hline Veraison +4 weeks & 23.9 & $22.0 \mathrm{a}$ & 4.55 & $5.28 \mathrm{bc}$ & 3.45 & 3.27 & $1.79 \mathrm{~b}$ & $1.34 \mathrm{a}$ \\
\hline \multirow[t]{2}{*}{ Veraison +6 weeks } & 23.8 & $22.5 \mathrm{abc}$ & 4.52 & $1.72 \mathrm{ab}$ & 3.46 & 3.23 & $1.79 \mathrm{~b}$ & $1.36 \mathrm{ab}$ \\
\hline & $\mathrm{ns}^{\mathrm{c}}$ & & ns & & ns & ns & & \\
\hline
\end{tabular}

${ }^{\mathrm{a}}$ Values with the same letter within the same column do not differ significantly (P > 0.05); ${ }^{\mathrm{b}}$ level of anthocyanins in whole berryhomogenates; ${ }^{\mathrm{C}}$ no significant difference.

\subsection{Wine Analysis}

Levels of total anthocyanins are shown in Table 5. Timing of thinning had no significant effect on wine anthocyanin levels relative to the control in either year. Additionally, there were no significant treatment effects on the proportions of the monomeric anthocyanins in the wines, data not shown. In contrast, thinning effects on wine phenolics were more pronounced. All thinning treatments significantly increased phenolics relative to the control in 2008, apart from the two latest treatments at veraison +4 and +6 wks. The effect on wine phenolics in 2009 was not as evident with only the inflorescence swelling and veraison stages being significantly higher. The higher crop loads in 2009 and the earlier harvest may have influenced the levels of phenolics.

\subsection{Vine Balance}

Comparisons of pruning data and vine balance indices between the thinning treatments are shown in Table 6 . The thinning treatments had no significant effects on vine vegetative growth in either season based on measurements of mean cane weight and pruning weight. Relative to optimal values cited [21], the study vines had excessive vegetative growth, in line with excessive leaf area indicated in Table 1 . There was no significant effect of crop removal on the yield:pruning weight ratios in 2008, and the low levels for that season indicate vine imbalance with excessive vigour present. The higher crop load carried in 2009 resulted in larger ratios with significant differences between the control and thinning at preflowering, and from veraison and later only. In the 2008 season, the canopy surface area was appropriate to the yield, even for control vines. For 2009, the control vine value was higher than the proposed optimum suggesting that the exposed canopy surface area may be limiting for ripening. However, all thinning treatments especially later in the season were within the optimum range $\left(1.0\right.$ to $\left.1.5 \mathrm{~kg} / \mathrm{m}^{2}\right)$.

Data on leaf area was only collected in the 2008 season, and the canopy leaf area: yield index is presented in Table 6. Results ranged from unthinned control vines at $1.7 \mathrm{~m}^{2} / \mathrm{kg}$ and for the first five crop thinning treatments the average was $2.7 \mathrm{~m}^{2} / \mathrm{kg}$, both well in excess of the optimum range of 0.8 to $1.2 \mathrm{~m}^{2} / \mathrm{kg}$ [21]. Leaf area appeared non limiting for ripening in 2008.

\section{Discussion}

Timing of thinning had no significant effect on Merlot berry weight in either season of study. This is similar to the results shown with Syrah [15] comparing thinning at bunch closure and veraison where no effect was noted on berry weight. Different trends were noted for white wine grape varieties, for both Vidal blanc [17] and for 
Table 5. Comparison of total phenolics and anthocyanin levels in Merlot wines 2008 and 2009.

\begin{tabular}{|c|c|c|c|c|}
\hline \multirow{2}{*}{ Stage of Cluster Thinning } & \multicolumn{2}{|c|}{$\begin{array}{l}\text { Total Anthocyanins as Malvidin } \\
\text { equivalents } \mathrm{mg} / \mathrm{L}\end{array}$} & \multicolumn{2}{|c|}{$\begin{array}{l}\text { Phenolics as catechin } \\
\text { equivalents } \mathrm{mg} / \mathrm{L}\end{array}$} \\
\hline & 2008 & 2009 & 2008 & 2009 \\
\hline Control & $356.8 \mathrm{a}^{\mathrm{a}}$ & $482.3 \mathrm{ab}$ & 4233 a & 4250 a \\
\hline Inflorescence swelling & 409.8 a & $554.5 \mathrm{~b}$ & $6188 \mathrm{~b}$ & $5173 \mathrm{~cd}$ \\
\hline $80 \%$ capfall & 423.9 a & $515.5 \mathrm{ab}$ & $6084 \mathrm{~b}$ & $4871 \mathrm{abc}$ \\
\hline Fruitset & 403.3 a & $532.3 \mathrm{ab}$ & $6095 \mathrm{~b}$ & 4962 abc \\
\hline Bunch closure & 434.1 a & $503.8 \mathrm{ab}$ & $6038 \mathrm{~b}$ & 4840 abc \\
\hline Veraison & $441.1 \mathrm{a}$ & $532.5 \mathrm{ab}$ & $6358 \mathrm{~b}$ & 5412 c \\
\hline Veraison +2 weeks & $417.1 \mathrm{a}$ & $519.3 \mathrm{ab}$ & $5905 \mathrm{~b}$ & 4798 abc \\
\hline Veraison +4 weeks & 395.1 a & 468.8 a & $5520 \mathrm{ab}$ & $4633 \mathrm{ab}$ \\
\hline Veraison +6 weeks & $431.0 \mathrm{a}$ & $506.0 \mathrm{ab}$ & $5750 \mathrm{ab}$ & 4918 abc \\
\hline
\end{tabular}

$\mathrm{a}^{\mathrm{a}}=$ values in the same column with the same letter do not differ significantly $(\mathrm{P}>0.05)$.

Table 6. Influence of timing of crop removal on Merlot vine growth and vine balance as measured by winter pruning data 2008 and 2009.

\begin{tabular}{|c|c|c|c|c|c|c|c|c|c|}
\hline \multirow{2}{*}{ Treatment } & \multicolumn{2}{|c|}{ Mean cane wt g } & \multicolumn{2}{|c|}{ Pruning wg kg/m } & \multicolumn{2}{|c|}{ Yield pruning wt kg/g } & \multicolumn{2}{|c|}{$\begin{array}{l}\text { Yield: canopy surface } \\
\text { area } \mathrm{kg} / \mathrm{m}^{2}\end{array}$} & \multirow{2}{*}{$\begin{array}{c}\begin{array}{c}\text { Leaf area: } \\
\text { yield } \mathrm{m}^{2} / \mathrm{kg}\end{array} \\
2008\end{array}$} \\
\hline & 2008 & 2009 & 2008 & 2009 & 2008 & 2009 & 2008 & 2009 & \\
\hline Control & 64.1 & 57.7 & 0.81 & 0.60 & 4.80 & $8.98 b^{\mathrm{a}}$ & $2.03 \mathrm{~b}$ & $2.90 \mathrm{c}$ & 1.74 \\
\hline Inflorescence swelling & 62.5 & 58.5 & 0.74 & 0.63 & 3.43 & $5.92 \mathrm{a}$ & $1.49 \mathrm{ab}$ & $2.17 \mathrm{ab}$ & 2.56 \\
\hline $80 \%$ capfall & 62.1 & 53.0 & 0.71 & 0.62 & 4.06 & $7.04 \mathrm{ab}$ & $1.44 \mathrm{ab}$ & $2.39 \mathrm{bc}$ & 2.54 \\
\hline Fruitset & 64.5 & 58.2 & 0.79 & 0.59 & 3.21 & $6.95 \mathrm{ab}$ & $1.39 \mathrm{ab}$ & $2.22 \mathrm{ab}$ & 2.73 \\
\hline Bunch closure & 60.2 & 55.9 & 0.77 & 0.58 & 3.57 & $6.76 \mathrm{ab}$ & $1.46 \mathrm{ab}$ & $2.01 \mathrm{ab}$ & 2.60 \\
\hline Veraison & 53.6 & 51.5 & 0.63 & 0.53 & 3.49 & $5.76 \mathrm{a}$ & $1.26 \mathrm{a}$ & $1.62 \mathrm{a}$ & 2.97 \\
\hline Veraison +2 weeks & 56.7 & 62.7 & 0.72 & 0.59 & 3.21 & 5.27 a & $1.24 \mathrm{a}$ & $1.69 \mathrm{a}$ & $\mathrm{nm}^{\mathrm{c}}$ \\
\hline Veraison +4 weeks & 59.1 & 45.3 & 0.71 & 0.50 & 3.17 & $5.71 \mathrm{a}$ & $1.10 \mathrm{a}$ & $1.62 \mathrm{a}$ & $\mathrm{nm}$ \\
\hline Veraison +6 weeks & 59.0 & 54.6 & 0.73 & 0.53 & 3.15 & $5.81 \mathrm{a}$ & $1.27 \mathrm{a}$ & $1.71 \mathrm{a}$ & $\mathrm{nm}$ \\
\hline Significance & \multicolumn{2}{|c|}{$n s^{b}$} & \multicolumn{2}{|c|}{ ns } & ns & & & & \\
\hline Optimum values & \multicolumn{2}{|c|}{$20-40$} & \multicolumn{2}{|c|}{$0.3-0.6$} & \multicolumn{2}{|c|}{$5-10$} & \multicolumn{2}{|c|}{$1.0-1.5$} & $0.8-1.2$ \\
\hline
\end{tabular}

${ }^{\mathrm{a}}$ Values with the same letter do not differ significantly $(\mathrm{P}>0.05)$; ${ }^{\mathrm{b}}$ no significant differences between the treatment, $\mathrm{nm}^{\mathrm{c}}=\mathrm{not}^{\mathrm{measured}}$

Chardonnay Musque [5] where cluster removal between bloom and veraison resulted in greater berry weights or cluster weights.

The impact of time of thinning on fruit composition varied with the season. In the lower crop season of 2008, fruit was more mature and there were no significant effects of time of thinning on sugar, titratable acidity (TA), or $\mathrm{pH}$. In 2009, the year of higher crop, sugar was increased by thinning at veraison, and TA decreased at five of the eight thinning stages. Berry anthocyanins were higher in 2008 than 2009, and all times of thinning increased values over the control. For the high crop season of 2009, only the thinning treatment at veraison increased the berry anthocyanin. Increased crop load and seasonal effects may have influenced the lower anthocyanin levels in 2009.

The fruit composition results for Merlot in this study are similar to those found for Shiraz in Western Australia [15]. These contrast with another study [8] where no beneficial effect from cluster thinning of Cabernet Sauvignon 
was found at either one month post-bloom or veraison on grape $\mathrm{pH}$ and anthocyanin levels, and significant increases in soluble solids in only two of the five years studied. Differences in fruit composition were influenced more by season than yield or crop load [18]. Seasonal effects on wine composition were also important in this study; wine anthocyanins were highest in 2009, in contrast to berry anthocyanins. There was no significant difference between timing treatments or the control for wine anthocyanin in either season. In 2008, the season of highest phenolics, the first six timing treatments showed an increase in phenolics. For the 2009 season, only the earliest time of thinning, and that at veraison were significantly higher for phenolics than control. In both seasons, thinning at veraison gave the highest or second highest values of anthocyanins and phenolics.

We now attempt to explain these treatment responses using standard viticultural indices, for vigour, balance and shading. The vines were high yielding, 15.9 and 22.7 t/ha for unthinned vines in 2008 and 2009 respectively, a $43 \%$ difference. They were also quite severely pruned, to only 25 buds per vine, and the mean pruning weight over both seasons was $1.1 \mathrm{~kg}$ per vine. It had been suggested [21] that 30 buds should be retained at winter pruning per kg pruning weight for achieving vine balance; the value in the test vineyard was 23 buds per $\mathrm{kg}$ pruning weight, a severe pruning level which will lead to under cropping and excess vigour. The control vines were vigorous, with 0.8 and $0.6 \mathrm{~kg}$ pruning weight per $\mathrm{m}$ row for 2008 and 2009. The vigour problem was worse for 2008, as published guidelines [21] are 0.3 to $0.6 \mathrm{~kg} / \mathrm{m}$. Similar differences were recorded for mean cane weight (64 g in 2008 and $58 \mathrm{~g}$ in 2009, with guideline optimum values 20 - $40 \mathrm{~g}$ ).

There are several indices for vine balance; one is that of yield to pruning weight, called the Ravaz index. Values for unthinned controls are 4.8 and 9.0 for 2008 and 2009 respectively, and the average of all thinned treatments 3.4 and 6.2. Quoted optimum values are 5 - 10, [4] [8] [21] which suggest that vines in 2008 were unbalanced and undercropped, with too much vegetative growth, made worse by thinning, but that in 2009 the balance was better, even for thinned vines. Another index of balance is yield per unit canopy surface area, with optimal values of $1.0-1.5 \mathrm{~kg} / \mathrm{m}^{2}$. Unthinned vines had values of 2.0 and $2.9 \mathrm{~kg} / \mathrm{m}^{2}$ for 2008 and 2009 respectively, both indicating "overcropping” relative to the canopy surface area. The situation was improved by thinning, with the average value for thinned vines respectively 1.3 and $1.9 \mathrm{~kg} / \mathrm{m}^{2}$ in 2008 and 2009 respectively.

The ratio of leaf area to fruit weight is another index related to ripening ability. Control unthinned vines had a value of $1.7 \mathrm{~m}^{2}$ per $\mathrm{kg}$ in 2008 , and $2.7 \mathrm{~m}^{2} / \mathrm{kg}$ the average for the first five thinning treatments. All are substantially in excess of an ideal value of $1.2 \mathrm{~m}^{2}$ per $\mathrm{kg}$ [21] and $0.8-1.2 \mathrm{~kg} / \mathrm{m}^{2}$ [25]. Finally, we consider canopy density and shading. This was assessed only in 2008 by point quadrat, the year of highest vigour and lowest crop. The optimum value for leaf layer number is 1.0 - 1.5 [21]; for control vines the value was 2.6, and the mean of the first five timing treatments 2.8. Excessively dense and shaded canopies are suggested, which is verified by calculating the ratio of canopy leaf area to surface area for 2008. Optimum values are given as less than 1.5 [21], which is easily exceeded by values of 2.4 for the control, and 2.3 for the average of the first five thinning treatments (data not presented).

In summary then, we can say that in both seasons the control vines were severely pruned, vigorous, excessively leafy, with high leaf to fruit ratio, and that the canopy was very shaded. Vines were better balanced in 2009, but still had a limited canopy surface area for the high yield. Therefore the results obtained are as expected, in that there was little grape and wine composition response to thinning in 2008 when vines were under cropped, and more in 2009 when the vines were in better balance.

Considering this situation one must question whether crop thinning is the most appropriate vineyard management for these unbalanced vines. A more desirable option would be to alter the training system to a divided canopy like the Scott Henry system, allowing more buds to be retained at pruning giving better vine balance, and the canopy surface area would be almost doubled, substantially reducing shading. However, due to the large bunches of Merlot, some thinning may still be required to avoid over cropping in seasons of higher fruitfulness.

Workers in Australia concluded that the Shiraz vines they studied were under cropped based on the low yield:pruning weight ratio [15], and this may explain why there was a minimal response recorded to the thinning strategies employed. A similar conclusion was drawn from the results with Chardonnay [5] and with Cabernet Sauvignon [18]. In contrast to these results, other researchers [17] noted that both the Vidal blanc and Chardonnay vines studied had yield:pruning weight indices exceeding 15 and concluded the vines were seriously overcropped, and this accounted for the beneficial effects on fruit quality from thinning prior to veraison.

\section{Conclusions}

Over the two seasons studied, the timing of crop removal by cluster thinning had no significant effect on subse- 
quent vine growth in terms of canopy density as measured by leaf growth, or enhanced shoot growth as measured by cane weights at pruning. Timing also had no effect on overall grape yield, cluster weight, and berry weight, even from thinning at pre-bloom. Grape ripeness at harvest in the 2009 season as measured by increased Brix and lower TA levels was significantly different from the control only at the veraison time of thinning. Higher crop loads in 2009 than 2008 may have influenced this result. Grape anthocyanin concentrations were enhanced by cluster thinning, and significantly more so when undertaken at or soon after veraison. There was no influence of time of thinning on anthocyanin levels and total phenolics in the wines made from these grapes.

Indices of vine balance suggest the vines were excessively leafy and could be considered undercropped, especially in 2008. The vine canopies were limited in exposed surface area, and excessively dense and shaded, which precludes a response to fruit thinning. The limited thinning response noted in the grapes and wine composition may be explained in terms of lowering the yield: canopy surface area ratios, but these values were anyway in the optimal range. Regardless, the time when cluster thinning was undertaken had little significant effect on grape ripeness and must and wine composition, although there was an indication of a greater response from crop removal at veraison.

\section{Acknowledgements}

The authors gratefully acknowledge financial support for this research from the Business Links Fund of the New Zealand Tertiary Education Commission. The authors thank Karen Ball and Melissa Annand for technical assistance, and the owners of Terra Rossa Vineyards for access to the vines and the provision of grapes.

\section{References}

[1] Petrie, P.R. and Clingeleffer, P.R. (2006) Mechanical and/or Hand Thinning of Cabernet Sauvignon. Australian Journal of Grape and Wine Research, 12, 21-29. http://dx.doi.org/10.1111/j.1755-0238.2006.tb00040.x

[2] Wolf, T.K., Dry, P.R., Iland, P.G., Botting, D., Dick, J., Kennedy, U. and Ristic, R. (2003) Response of Shiraz Grapevines to Five Different Training Systems in the Borossa Valley, Australia. Australian Journal of Grape and Wine Research, 9, 82-95. http://dx.doi.org/10.1111/j.1755-0238.2003.tb00257.x

[3] Chapman, D.M., Matthews, M.A. and Guinard, J.-X. (2004) Sensory Attributes of Cabernet Sauvignon Wines Made From Vines with Different Crop Yields. American Journal of Enology and Viticulture, 55, 325-334.

[4] Reynolds, A.G., Yerle, S., Watson, B., Price, S.F. and Wardle, D.A. (1996) Fruit Environment and Crop Level Effects on Pinot Noir. III. Composition and Descriptive Aanalysis of Oregon and British Columbia Wines. American Journal of Enology and Viticulture, 47, 329-339.

[5] Reynolds, A.G., Schlosser, J., Power, R., Roberts, R., Willwerth, J. and de Savigny, C. (2007) Magnitude and Interaction of Viticultural and Enological Effects. l. Impact of Canopy Management and Yeast Strain on Sensory and Chemical Composition of Chardonnay Musque. American Journal of Enology and Viticulture, 58, 12-24.

[6] Coombe, B.G. (1995) Adoption of a System for Identifying Grapevine Growth Stages. Australian Journal of Grape and Wine Research, 1, 100-110. http://dx.doi.org/10.1111/j.1755-0238.1995.tb00086.X

[7] Ough, C.S. and Ngaoka, R. (1984) Effect of Cluster Thinning and Vineyard Yields on Grape and Wine Composition and Wine Quality of Cabernet Sauvignon. American Journal of Enology and Viticulture, 35, 30-34.

[8] Bravdo, B., Hepner, Y., Loinger, C., Cohen, S. and Tabacman, H. (1985) Effect of Crop Level and Crop Load on Growth, Yield, Must and Wine Composition, and Quality of Cabernet Sauvignon. American Journal of Enology and Viticulture, 36, 125-131.

[9] Prajitna, A., Dami, I.E., Steiner, T.E., Ferree, D.C., Scheerens, J.C. and Schwartz, S.J. (2007) Influence of Cluster Thinning on Phenolic Composition, and Antioxidant Capacity in Chambourcin Wine. American Journal of Enology and Viticulture, 58, 346-350.

[10] Guidioni, S.A., Ferrandino, A. and Novello, V. (2008) Effects of Seasonal and Agronomical Practices on Skin Anthocyanin Profile of Nebbiolo Grapes. American Journal of Enology and Viticulture, 59, 22-29.

[11] Mattii, G.B. and Ferrini, F. (2005) The Effects of Crop Load on "Sangiovese” Grapevines. In: Williams, L.E., Ed., ISHS Acta Horticulturae 689: VII International Symposium on Grapevine Physiology and Biotechnology, ISHS, Davis, California, USA, 239-242.

[12] Nuzzo, V. and Matthews, M.A. (2006) Response of Fruit Growth and Fruit Ripening to Crop Level in Dry-Farmed Cabernet Sauvignon on Four Rootstocks. American Journal of Enology and Viticulture, 57, 314-324.

[13] Pena-Neira, A., Caceres, A. and Pastenes, C. (2007) Low Molecular Weight Phenolic and Anthocyanin Composition of Grape Skins from cv. Syrah (Vitis vinifera L.) in the Maipo Valley (Chile): Effect of Clusters Thinning and Vineyard 
Yield. Food Science and Technology Internationals, 13, 153-158. http://dx.doi.org/10.1177/1082013207077920

[14] Jackson, D.I. and Lombard, P.B. (1993) Environmental and Management Practices Affecting Grape Composition and Wine Quality-A Review. American Journal of Enology and Viticulture, 44, 409-430.

[15] McDonald, C., Bell, S.-J., Lantzke, N. and Kennison, K. (2005) Bunch Thinning: When Is the Best Time to Thin, and Is It Worthwhile. Australian \& New Zealand Grapegrower \& Winemaker, Annual Technical Issue, 40-46.

[16] Dokoozlian, N.K. and Hirschfelt, D.J. (1995) The Influence of Cluster Thinning at Various Stages of Fruit Development on Flame Seedless Table Grapes. American Journal of Enology and Viticulture, 46, 429-436.

[17] Ferree, D.C., Cahoon, G.A., Scurlock, D.M. and Brown, M.V. (2003) Effect of Time of Cluster Thinning of Grapevines. Small Fruits Review, 2, 3-14. http://dx.doi.org/10.1300/J301v02n01_02

[18] Keller, M., Mills, L.J., Wample, R.L. and Spayd, S.E. (2005) Cluster Thinning Effects on Three Deficit-Irrigated Vitis vinifera Cultivars. American Journal of Enology and Viticulture, 56, 91-103.

[19] King, P.D., McClellan, D.J. and Smart, R.E. (2012) Effect of Severity of Leaf and Crop Removal on Grape and Wine Composition of Merlot Grapevines in Hawke's Bay, New Zealand. American Journal of Enology and Viticulture, 63, 500-507. http://dx.doi.org/10.5344/ajev.2012.12020

[20] Griffiths, E. (2001) Soils of the Heretaunga Plains-A Guide to Their Management. Grifftech and Hawke’s Bay Regional Council, Napier, $102 \mathrm{p}$.

[21] Smart, R.E. and Robinson, M. (1991) Sunlight into Wine: A Handbook for Winegrape Canopy Management. Winetitles, Adelaide.

[22] Iland, P.G., Cynkar, W., Francis, I.L., Williams, P.J. and Coombe, B.G. (1996) Optimisation of Methods for the Determination of Total and Red-Free Glycosyl Glucose in Black Grape Berries of Vitis vinifera. Australian Journal of Grape and Wine Research, 2, 171-178. http://dx.doi.org/10.1111/j.1755-0238.1996.tb00105.x

[23] Iland, P., Ewart, A., Sitters, J., Markides, A. and Bruer, N. (2000) Techniques for Chemical Analysis and Quality Monitoring during Winemaking. Patrick Iland Wine Promotions, Campbelltown, 98-100.

[24] Green, S. (2008) Measurement and Modelling the Transpiration of Fruit Trees and Grapevines for Irrigation Scheduling. In: Goodwin, I. and O’Connell, M.G., Eds., Acta Horticulturae 792: Proceedings of the Fifth International Symposium on Horticultural Crops, ISHS, Leuven, 321-327.

[25] Kliewer, W.M. and Dokoozlian, N.K. (2005) Leaf Area/Crop Weight Ratios of Grapevines: Influence on Fruit Composition and Wine Quality. American Journal of Enology and Viticulture, 56, 170-181. 